\title{
Conceptualising primary labour relationship quality
}

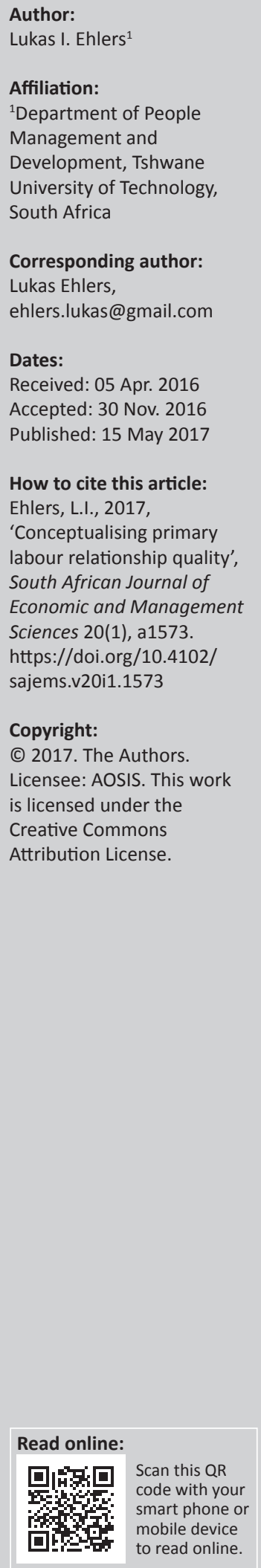

Author:

Affiliation

${ }^{1}$ Department of People

University of Technology,

Lukas Ehlers,

Dates:

Received: 05 Apr. 2016

Accepted: 30 Nov. 2016

How to cite this article:

Ehlers, L.I., 2017,

conceptualising primary

South African Journal of

Economic and Management

Copyright:

C) 2017. The Authors.

is licensed under the

Creative Commons

Attribution License.
Background: A typology of desirable social conditions in supervisory relationships suggested that such conditions may also be desirable in other forms of labour relationships. A literature review confirmed that trust, compliance, fairness and good faith can be confidently regarded as universally desirable social conditions in all forms of individual or collective labour relationships between employers and employees.

Aim: The purpose of this study was to determine if primary labour relationship quality (PLQ) can be confidently conceptualised as a social construct that strongly relates to the perceived levels of compliance, fairness and good faith in supervisory or primary labour relationships.

Setting: A combination of random and convenience sampling approaches was implemented to collect PLQ related data from 454 voluntary respondents, who were subordinate employees in the Tshwane region.

Methods: A quantitative research methodology was adopted. This included conceptual definition of the PLQ construct, objective measurement of PLQ levels of voluntary respondents in an adequately sized sample, factor analysis and testing for relationships and differences in means between variables.

Results: Data analysis results confirmed that it can be confidently concluded that the conceptual definition of PLQ was valid, and that positive PLQ perceptions of subordinate employees were significantly related to at least two other forms of desirable organisational outcomes.

Conclusion: PLQ perceptions can be confidently defined as a distinct subjective quality estimate that is assimilated from unique expectations and perceptions of the levels of compliance, fairness, good faith and trust that a supervisor displays in a labour relationship with an immediate subordinate.

\section{Introduction \\ Background}

Labour relations is a field of study that examines all forms of relationships that occur between any number of people who are related through some or other form of labour, and the internal and external environmental variables that influence the expectations, perceptions and behaviour of primary and secondary relationship stakeholders. Labour relations can occur at different levels, for example, supervisory, departmental, organisational, industrial, national or international. However, most individual labour relationship exchanges will typically occur between individual subordinates and their supervisors within their unique workplace environment. Such relationships can subsequently be regarded as primary labour relationships, which are different from secondary labour relations that occur between groups of employees, or their representatives, and their employers, or their representatives. It should be noted that authors often use the term employment relations to describe primary and secondary labour relationships. However, the term primary labour relations will be preferred in this study to ensure focus on labour relationship behaviour in supervisory relationships. In this context, tertiary labour relations will be regarded as relationships between organised groups of employees and employers, or their representatives and the state, as well as other macro-level stakeholders (Bendix 2015; Nel et al. 2016; Venter \& Levy 2015).

The work-related expectations, values, attitudes, perceptions and behaviour of subordinates can be influenced by supervisory behaviour in a variety of ways (Robbins \& Judge 2013). Perceived organisational support (POS) theorists believe that subordinates in supervisory relationships regard the values and behaviour of their immediate supervisors as the values and behaviour of the employer as a whole (Shanock \& Eisenberger 2006). In addition to their routine supervisory duties, South African supervisors are also expected to deal effectively with a variety of dynamic 
and unpredictable labour relationship challenges emanating from a socially sensitive, politically aware and economically challenging labour market, (Moloto, Brink \& Nel 2014; Soko \& Belchin 2014). They should thus be highly alert and cautious when dealing with labour relations challenges, and be especially aware of the negative consequences that socially undesirable behaviour holds for the organisations in which they are employed, as well as the society in which they live (Ntimba 2015). However, supervisors are not the sole custodians of good-quality labour relationship behaviour. The elimination of undesirable and promotion of desirable relationship behaviours at the organisational-, industrialand societal-level labour relations should be regarded as a critically important responsibility and competency of all labour relations stakeholders, irrespective of their unique roles or relationship environments.

The question that subsequently begs to be answered is: 'Which desirable labour relationship behaviours and social conditions are typically present in good quality labour relationships?' Ehlers (2013) found that trust, justice, fairness and good faith were typically desirable social conditions in supervisory relationships. However, in a subsequent paper, Ehlers (2014) considered the formal, normative and psychological dimensions of employment contracting, and then proposed that trust, compliance, fairness and good faith are universally desirable social conditions in labour relationships. The ambiguous term 'justice' was thus replaced by 'compliance', which more specifically denotes observance of applicable laws, agreements, contracts, policies, codes and procedures. It can therefore be confidently expected that perceptions of the levels of compliance, fairness, good faith and trust in labour relationships will be strongly related to assessments of the quality of labour relationships, and for purposes of this study, primary labour relationships between individual subordinates and supervisors.

\section{Research objective}

Gay and Weaver (2011) believed that research into the nature and validity of theoretical constructs can facilitate incremental understanding and explanation of a theory. They were of the opinion that any advance in the definition, expansion or validation could be regarded as an advancement of knowledge that is aimed at the eventual revelation of scientifically founded truths, and encouraged researchers to undertake more quantitative, qualitative and mixed method research studies relating to theory building. These views confirmed that quantitative research into validity of the primary labour relationship quality (PLQ) construct would advance scientific knowledge on labour relationship and organisational behaviour in South African organisations, to some or other extent.

A survey of labour relationship and supervisory behaviour articles in leading South African labour relations and human resource management journals, confirmed that no unique theory on the quality of employment or labour relationship behaviour in supervisory relationships was published in the last 10 years. It was therefore decided to consolidate and build on the work of Ehlers $(2013,2014)$ by developing a conceptual definition of PLQ as a theoretical construct, and testing the validity of a newly conceptualised theoretical construct in accordance with a reliable validation methodology (Cresswell 2014; Friedman 2003; Gay \& Weaver 2011; Snow \& Thomas 1994).

\section{Overview}

The contention of this article is that PLQ is a distinct theoretical construct that relates to unique individual labour relationship expectation, perceptions and behaviours in supervisory relationships. The nature and validity of the PLQ construct, and related concepts, will subsequently be investigated and discussed in the remainder of this article. The following sections contain a literature review on the nature of labour relationship exchanges in good-quality primary labour relationships, and a discussion of the research methodology. These sections will be followed by a discussion of findings on the validity of PLQ as a theoretical construct. Limitations, recommendations and final conclusions will be discussed in the closing section.

\section{Literature review Poor-quality labour relationships}

Supervisors are key leaders and change facilitators in organisations, and need to ensure that subordinates perform their duties at expected levels, by effectively planning, organising, leading and controlling their activities. They also need to ensure that a variety of formal and psychological contracting expectations of subordinates with diverse demographic characteristics are met, in order to establish and maintain good-quality labour relationships (Botha \& Moalusi 2010; Robbins \& Judge 2013; Tepper 2007). Numerous empirical studies confirmed that employees respond negatively to abusive or negative supervisor behaviour by engaging in deviant behaviour forms that could be harmful to the organisation and its members, such as poor work performance, deviant work behaviour or resignation outcomes (Guest 2004; Tekleab \& Taylor 2003; Theledi 2015). Positive supervisor treatment, on the contrary, promotes job satisfaction, employment relationship satisfaction, organisational trust as well as a host of other positive organisational (Robbins \& Judge 2013).

Many South African supervisors, unfortunately, do not appreciate; respect; or promote trust, compliance, fairness and good faith in their relationships with subordinates. Such neglect can result in negative subordinate perceptions of their job security, transparency, job satisfaction and the quality of labour relationships with supervisors and their employers (Ntimba 2015). The Commission for Conciliation, Mediation and Arbitration (CCMA) (2011) identified numerous forms of illegal and unfair supervisory behaviour since its inception. These behaviours are believed to be causes of workplace tension, workplace conflict, formal grievances and labour disputes. These negative outcomes are mostly 
related to some form of non-compliant, unfair or bad faith behaviour of a supervisor or manager (Theledi 2015).

The following behaviour forms are examples of undesirable supervisor behaviour: mental bullying of subordinates; ridiculing subordinates in the presence of others; preferring a less deserving candidate for promotion; not considering employees for progress on grounds of race, gender, language, culture, religion, union affiliation or age; victimising subordinates; allowing privileges to selected employees on subjective grounds; and allowing special privileges to selected employees or intentionally blocking promotion and progress (CCMA 2011). The mere presence of the aforementioned undesirable behaviours in the South African labour market confirms the need for theories, measures, strategies, policies and practices aimed at improving PLQ in the South African labour market (Ntimba 2015; Soko \& Belchin 2014).

\section{Labour relations dimensions}

Labour relationship exchanges occur in formal and psychological contracting dimensions (Guest 2004; Navarro \& Cabrera 2009). Grogan (2014) defined a formal employment contract as a voluntary agreement between two legal parties in terms of which an employee undertakes to place his or her personal services at the disposal of the employer for an indefinite or determined period of time in return for a fixed or ascertainable remuneration. Formal employment contracts empower employers to define an employee's duties and to control the manner in which the employee discharges them, provided that reasonable support is given to an employee. Employers and employees should, however, not exploit each other, and both parties are under a legal obligation to comply with explicitly defined legal and contractual provisions (Overell et al. 2010). The parties to an employment contract may not change contract provisions without the consent of the other contracting party, and may terminate the contract by serving agreed notice or for other legally sound reasons (Grogan 2014).

Psychological contracting rights and duties are, unfortunately, not as clearly defined as formal contracting rights and duties. Psychological contracts can be defined as a set of mostly subjective beliefs, expectations or perceptions of what an employee, or employer, should be receiving in a labour relationship, and what the labour relationship partner should be receiving in return. They are based on unspoken needs and expectations that fall outside the scope of formal labour contracts and collective agreements (Guest 2004; Overell et al. 2010). Psychological contracts encapsulate vague and subjective perceptions on the nature and quality of trust, honesty, respect, constructivity, consideration, fairness, good faith and reciprocity in work relationships. Employers and employees form subjective perceptions on the degree to which their expectations in the aforementioned aspects were met by their relationship partners. A perceived breach of a psychological contract can result in relationship tension, relationship conflict, undesirable relationship behaviour and the eventual termination of an employment contract (Botha \& Moalusi 2010; Gerlach et al. 2007; Guest 2004; Tekleab \& Taylor 2003).

\section{Desirable social conditions in primary labour relationships}

Trust, compliance, fairness and good faith were identified as four primary desirable social conditions in labour relationships (Ehlers 2014; Ehlers \& Jordaan 2016). All four of these social conditions are explicitly or implicitly regulated by South African labour law and related case law emanating from Labour Court rulings and CCMA awards (Grogan 2014). Each of these social conditions encapsulates five distinctive but interrelated behaviour forms that are indicative of the prevalence of each respective social condition in supervisory relationships (Ehlers \& Jordaan 2016). The following sections contain discussions on the nature of each of the four desirable social conditions in labour relationships.

\section{Trust in primary labour relationships}

Perceptions of trust, consistency, fairness, equity and good faith are strongly interrelated and stem from relationship expectations and exchanges which occur in the formal and psychological dimensions of labour contracting (Cropanzano, Bowen \& Gilliand 2007). Trust can be simply defined as the willingness of a party (trustor) to be vulnerable to the actions of another party (trustee) based on the expectation that the trustee will perform one or more actions that are important to the trustor, even if the trustor is unable to monitor or control the trustee (Sparrow \& Cooper 2003). Coyle-Shapiro and Shore (2008) concluded that employees with high levels of trust in their organisations are thus more likely to put greater effort into their roles and co-operate better with others in the workplace, while employees with low levels of trust in their organisations are likely to interact and work less effectively.

Even though trust is regarded as a foundation for effective and harmonious labour relationships, there are no laws that require high levels of trust in a labour contract, rule or regulation to make it valid (Williams 2007). Employers, however, are under an implied obligation to create certainty, fairness, equity and consistency in workplace relationships, which mostly requires compliance with labour laws and contractual stipulations, legitimate labour policies and legitimate labour procedures (Grogan 2014). Trustworthy relationship partners are more likely to be convinced of relationship objectives and partner bona fides, devoted to relationship objectives and duties, tolerant of partner shortcomings and unforeseen relationship duties, supportive of relationship partners and loyal to relationship partners (Tekleab \& Taylor 2003; Williams 2007).

It should also be noted that employees need to perceive employer behaviour and procedures as justified and fair in order to have trust in them, and to behave in accordance with related employer expectations (Linde, Schalk \& Linde 2008; Williams 2007). Low levels of trust in labour relationships are strongly related to negative relationship outcomes, but a 
climate of trust facilitates open and constructive relationship interaction which can prevent personal differences from evolving into negative or dysfunctional forms of workplace conflict (Flanagan \& Runde 2009; Williams 2007). Ehlers and Jordaan (2016) were of the opinion that conviction, devotion, support, tolerance and loyalty are core indicators of trust in good-quality labour relationships. Trust, or perceived trust, is subsequently expected to be strongly related to positive PLQ perceptions of subordinates in supervisory relationships.

\section{Compliance in primary labour relationships}

Actual levels of legal or contractual compliance can rarely be objectively assessed by supervisors or subordinates because of their limited knowledge and understanding of applicable labour laws, contracts and often complicated legal principles (Ntimba 2015). Compliance with the Constitution, labour legislation, labour contracts or collective agreements, workplace directives and formal procedures provides foundations and boundaries for labour relationship behaviour (Bendix 2015; Ehlers \& Jordaan 2016; Grogan 2014). Figure 1 reflects the relationship between the various sources of labour law, contracts and workplace procedures.

Holtz and Harold (2009) concluded that there is a strong relationship between procedural justice perceptions of employees and organisational trust levels. These perceptions relate to the implementation of formal labour relationship rules and regulations. Research also confirmed that perceived procedural compliance can create powerful mutually beneficial social conditions in labour relationships such as trust and commitment, improved job performance, positive citizenship outcomes, improved customer satisfaction and diminished conflict in organisational relationships (Cropanzano et al. 2007; Linde et al. 2008). Compliance, or perceived compliance, is accordingly expected to be strongly related to positive PLQ perceptions of subordinates in supervisory relationships.

\section{Fairness in primary labour relationships}

Fair labour relationship exchanges are more likely to occur when relationship partners are informed, objective, equitable, consistent and reciprocal (Ehlers \& Jordaan 2016; Salamon 1987). A labour relationship partner could subsequently perceive unfair treatment when these expectations are not met during relationship exchanges. Kickul, Gundry and Posig (2005) found that employees are likely to be more sensitive to issues of fairness and equity when trust levels in the labour relationship are low.

Perceived unfairness and low trust levels can trigger undesirable subordinate conduct (Southey 2010). Gerlach et al. (2007) found that subordinate employees who experience unfair treatment may deliberately restrict output or even resort to sabotage, and that employees who feel fairly treated

\begin{tabular}{|c|c|}
\hline $\begin{array}{l}\text { EXPECTATIONS OF FAIRNESS AND GOOD FAITH } \\
\text { The trust relationship between employers and employees can be maintained and promoted when both parties are willing to reciprocate legitimate expectations } \\
\text { of fairness and good faith in all forms of employment relationship exchanges. Employment relationship trust is founded on compliance with all } \\
\text { applicable formal workplace rules, codes and procedures. }\end{array}$ & \\
\hline $\begin{array}{l}\text { FORMAL WORKPLACE RULES, CODES AND PROCEDURES } \\
\text { Formal workplace rules, codes and procedures must be complied with in addition to all other provisions in formal employment contracts. }\end{array}$ & $\begin{array}{l}\text { A } \\
\text { S } \\
\text { E }\end{array}$ \\
\hline $\begin{array}{l}\text { FORMAL EMPLOYMENT CONTRACTS } \\
\begin{array}{l}\text { Formal labour contracts, or summaries of employment conditions, must comply with employer directives and policies, as well as applicable } \\
\text { collective agreements, codes of conduct, determinations and statutory labour laws. }\end{array}\end{array}$ & $\begin{array}{l}\mathrm{L} \\
\mathrm{A} \\
\mathrm{W}\end{array}$ \\
\hline $\begin{array}{l}\text { EMPLOYER DIRECTIVES AND POLICIES } \\
\text { Written and unwritten employment directives (visions, missions, objectives, strategies, policies) must comply with all applicable collective agreements, or } \\
\text { codes of conduct, determinations and statutory labour laws if there are no applicable collective agreements. }\end{array}$ & $\begin{array}{l}\text { P } \\
\text { R } \\
\text { E }\end{array}$ \\
\hline $\begin{array}{l}\text { COLLECTIVE AGREEMENTS } \\
\text { All forms of collective agreements must comply with all applicable determinations, codes of good conduct and applicable statutory labour laws. }\end{array}$ & $\begin{array}{l}\text { C } \\
\text { E } \\
\text { D }\end{array}$ \\
\hline $\begin{array}{l}\text { CODES OF GOOD CONDUCT AND DETERMINATIONS } \\
\text { Codes of good conduct and sectoral or ministerial determinations are extensions of statutory labour laws and must be complied } \\
\text { with in addition to statutory labour laws. }\end{array}$ & $\begin{array}{l}\mathrm{E} \\
\mathbf{N} \\
\mathrm{T} \\
\mathbf{S}\end{array}$ \\
\hline $\begin{array}{l}\text { STATUTORY LABOUR LAWS } \\
\text { Laws that dictate the nature of labour contracts in order to regulate various aspects of labour relations, e.g. LRA, EEA, BCEA, OHSA, COIDA, UIA and SDA } \\
\text { must be complied with in addition to compliance with common law contracting principles. }\end{array}$ & \\
\hline $\begin{array}{l}\text { COMMON LAW CONTRACTING PRINCIPLES } \\
\text { Common law contracting principles must be respected in all types of contracts in addition to Constitutional compliance. }\end{array}$ & \\
\hline $\begin{array}{l}\text { THE CONSTITUTION OF THE RSA } \\
\text { All workplace conduct in South Africa must comply with all Constitutional provisions. }\end{array}$ & \\
\hline
\end{tabular}

LRA, Labour Relations Act; EEA, Employee Equity Act; BCEA, Basic Conditions of Employment; OHSA, Occupational Health and Safety Act; COIDA, Compensation for Occupational Injuries and Diseases Act; UIA, Unemployment Insurance Act; SDA, Skills Development Act.

Figure 1: Labour relationship compliance framework. 
are more likely to perform above minimum requirements. DiMatteo, Bird and Colquitt (2011) further found that procedural or substantive unfairness in the termination of labour contracts were positively related to increased propensities to retaliate and litigate. The effect on propensities of employees to retaliate or litigate was also amplified when a termination was perceived to be procedurally and substantively unfair. Fairness, or perceived fairness, is therefore expected to be strongly related to positive PLQ perceptions of subordinates in supervisory relationships.

\section{Good faith in primary labour relationships}

Good faith can be defined as an honest and sincere intention to create mutual benefit for all parties in a relationship by displaying interested, sincere, respectful, considerate and constructive behaviour in relationship exchanges (Ehlers \& Jordaan 2016; Heap 2009; Riley 2009). Bad faith will become evident when disinterested, insincere, disrespectful, selfish or obstructive behaviour is adopted in relationship exchanges (Shimanskaya 2010).

Positive perceptions of good faith are related to higher levels of trust in organisational relationships, which in turn strongly relate to a number of positive organisational behaviour outcomes (Botha \& Moalusi 2010; Guest 2004; Tekleab \& Taylor 2003). The research of Searle and Skinner (2011) further confirmed that employee trust levels are determined by individual relationship experiences and subjective perceptions related to management behaviour and other social variables in a labour relationship. It can thus be confidently expected that general PLQ perceptions will be strongly related to the perceived good faith in their relationship with immediate supervisors.

\section{Summary}

The literature review confirmed that formal and psychological contract expectations, such as trust, compliance, fairness and good faith influence labour relationship perceptions and behaviour in labour relationships. Lower levels, or absence, of trust, compliance, fairness and good faith are related to negative or undesirable primary labour relationships or organisational behaviour forms or outcomes. Each of the four desirable social conditions in primary labour relationships encapsulates at least five distinct, yet interrelated, behaviour forms. These behaviours promote positive subordinate perceptions of the quality of trust, compliance, fairness and good faith in primary labour relationships (see Table 1). The aforementioned social conditions and related behaviours can thus be confidently expected to be significantly related to general subordinate estimates of PLQ.

\section{Research methodology}

A quantitative research design that could facilitate the validation of a theoretical construct and a related measure was required for this study (Cresswell \& Plano Clark 2007). A literature review and a questionnaire survey were consequently undertaken and quantified responses were captured and statistically analysed from a modernist perspective. The following chronological steps were followed in this study (Babbie 2011; Bless, Higson-Smith \& Kagee 2013; Cresswell 2014; Field 2009; Kumar 2011):

- The background to the research problem and theoretical constructs were conceptualised.

- A literature review on the nature of labour relationships, supervision and desirable labour relationship behaviour was conducted, and the theoretical construct under investigation was clearly defined.

- A reliable theoretical construct development and validation procedure was identified. The aforementioned procedure will be comprehensively discussed in the following section.

- A valid and reliable measure of labour relationship quality was identified and included in a survey questionnaire along with a number of general biographical items (Ehlers \& Jordaan 2016). In addition, the survey questionnaire also included valid and reliable measures of workplace self-esteem (WSE) and quit intention for a related research study. The availability of trustworthy measurements of the latter variables, however, provided an ideal opportunity to test hypotheses on the relationship

TABLE 1: Facilitators of good-quality labour relationships.

\begin{tabular}{lll}
\hline Variable & \multicolumn{1}{c}{ Relationship partners } & \multicolumn{1}{c}{ Evident when parties are } \\
\hline Trust & $\begin{array}{l}\text { Willing to risk vulnerability by relying on a relationship } \\
\text { partner to behave in an expected manner }\end{array}$ & - Convinced (undoubted acceptance of relationship objectives and partner bona fides) \\
& & - Devoted (committed to relationship objectives and performance of relationship duties) \\
Compliance & Tolerant (accepting relationship partner shortcomings and unforeseen relationship duties) & - Supportive (encouraging or assisting relationship partners to perform their duties) \\
& labour relationship exchanges & - Loyal (acting in the best interest of a relationship partner - not exploiting partner vulnerabilities)
\end{tabular}


between PLQ and other organisational variables (see section 'Experimentation and hypothesis testing').

- A combination of random and convenience sampling approaches was implemented to collect data from voluntary respondents in the Tshwane region (Bless et al. 2013). A group of field workers were briefed on the nature of the research study, the survey questionnaire and the ethical aspects of survey questionnaire methods. Field workers were requested to approach potential respondents randomly, explain the nature of the research study and then request potential respondents to read and accept an ethical compliance statement in the preamble of the questionnaire, if they were willing to complete the questionnaire as an anonymous, informed and consenting volunteer.

- A total of 454 completed questionnaires were returned (219 males and 235 females; 368 African race respondents and 86 from other race groups). A sample size of 454 was deemed to be large enough to conduct a meaningful exploratory factor analysis of questionnaire data (Hair et al. 2006).

- Questionnaire responses were then captured and analysed on a personal computer using SPSS version 20. A variety of general, descriptive and inferential statistical procedures were applied to structure and analyse data.

\section{Discussion of theory development and validation process}

A number of general guidelines for effective development and validation of a theoretical construct were reported in literature (Cresswell 2014; Friedman 2003; Gay \& Weaver 2011; Snow \& Thomas 1994). The following list contains the most important general requirements for effective theory development and validation:

- identify key constructs, concepts and variables

- describe relationships between phenomena and theoretical rationales

- determine boundary conditions of the theory

- develop a valid and reliable measure of key concepts and constructs

- establish the nature of relationships between variables

- test theory validity through critical experimentation and hypothesis testing.

Procedures and findings pertaining to each of the aforementioned requirements will be described in the following sections.

\section{Identification of key constructs and variables}

Primary labour relationship quality was initially conceptualised as a construct that refers to a distinct subjective quality estimate that is assimilated from unique expectations and perceptions that an individual subordinate holds on the quality or levels of compliance, fairness, good faith and trust that an immediate supervisor displays in an individual labour relationship.
The specific components of the above mentioned theoretical assumption should be understood as follows (Adapted from general definitions in Oxford Press (2010), and literature views relating to the PLQ theory under investigation):

- primary means first level or most important

- labour means to perform physical or mental work

- relationship refers to a unique association between two or more people

- distinct means unique and clearly different from other things or behaviours

- subjective means vague personal feelings, tastes or opinions

- quality refers to the standard of something as measured against other things

- estimate means an imprecise valuation of a value, number, quantity or extent

- assimilated means to integrate something that was obtained from other sources

- unique means different and other expectations and perceptions

- expectations are strong beliefs that an event or behaviour will occur

- perceptions are unique ways of regarding, understanding or interpreting behaviour

- individual subordinate refers to a specific person that works under instruction of a specific supervisor

- level refers to a specific position on a real or imaginary scale

- compliance means that relationship partners comply with formal relationship guidelines in all of their relationship exchanges

- fairness means that relationship partners treat each other in an even-handed manner in all relationship exchanges

- good faith means that relationship partners sincerely promote mutual relationship benefits in all relationship exchanges

- trust means that relationship partners are willing to risk vulnerability by relying on their relationship partner to behave in an expected manner

- immediate supervisor refers to a person who directly oversees the work of another person

- display means to show, demonstrate or exhibit behaviour

- individual labour relationship refers to a work-related relationship between two different persons.

\section{Relationships and theoretical rationales}

South African supervisors are expected to deal with a multitude of distinctive labour relationship challenges that emanate from transforming social, economic and political systems, in addition to their routine supervisory duties (Bendix 2015; CCMA 2011; Nel et al. 2016; Ntimba 2015; Soko \& Belchin 2014; Venter \& Levy 2015). They should therefore be especially attentive to the promotion of goodquality labour relationships, and make all efforts to avoid undesirable sociopolitical conflicts with subordinates. Displays of compliance, fairness, good faith and trust by 
supervisors have been found to promote good-quality labour relationships with subordinates (Ehlers \& Jordaan 2016).

At least five distinctive but interrelated behaviour forms can contribute to positive subordinate perceptions of compliance. The same applies to positive perceptions of fairness, good faith and trust in primary labour relationships. Twenty desirable labour relationship behaviour forms can thus be regarded as typical facilitators of good-quality primary labour relationships (Table 1). Supervisors should subsequently be ably encouraged to display these core desirable labour relationship behaviours to establish, maintain and promote good-quality primary labour relationships. Neglect of such behaviours can be expected to result in negative subordinate perceptions of PLQ and related negative organisational behaviours and outcomes (Cropanzano et al. 2007; DiMatteo et al. 2011; Flanagan \& Runde 2009; Gerlach et al. 2007; Grogan 2014; Holtz \& Harold 2009; Kickul et al. 2005; Linde et al. 2008; Overell et al. 2010; Searle \& Skinner 2011; Tekleab \& Taylor 2003; Williams 2007).

\section{Boundary conditions of the primary labour relationship quality theory under development}

Any new theory should be investigated in the context where it will be applied. Such investigations should be preceded by a clear conceptual definition (Cresswell 2014; Friedman 2003; Snow \& Thomas 1994). A conceptual definition of PLQ was provided in the section 'Identification of key constructs and variables'. Analysis of the conceptual definition and related literature, suggested that the following initial boundary conditions be respected:

- PLQ perceptions are related to individual expectations and experiences in the formal and psychological dimensions of labour relations (Botha \& Moalusi 2010; DiMatteo et al. 2011; Ehlers 2014).

- PLQ perceptions are distinctly different from subordinate perceptions of the quality of routine supervisory behaviours such as communicating, planning, organising, leading and controlling (Botha \& Moalusi 2010; Guest 2004; Robbins \& Judge 2013).

- PLQ perceptions result from very specific subordinate perceptions of compliance, fairness, good faith and trust in labour relationship exchanges that are distinctively rooted in the fields of labour relations and labour laws (Botha \& Moalusi 2010; Ehlers 2014; Grogan 2014; Guest 2004; Overell et al. 2010).

- PLQ perceptions are uniquely individual and can be estimated by any subordinate, regardless of race, gender, age, seniority, union affiliation or qualification among others (Botha \& Moalusi 2010; Ehlers \& Jordaan 2016; Robbins \& Judge 2013).

- Positive PLQ perceptions can be confidently expected to be positively related to numerous desirable organisational phenomena. For example, high productivity, job satisfaction, high workplace-based self-esteem, engagement, good citizenship behaviour, good work-life balance, positive diversity attitudes, lower stress levels, weak quit intention and wellness, among others. Conversely, negative perceptions are expected to be negatively related to desirable organisational phenomena (Botha \& Moalusi 2010; Delobelle et al. 2011; Joubert \& Roodt 2011; Linde et al. 2008; Robbins \& Judge 2013; Searle \& Skinner 2011).

- Negative PLQ perceptions can be confidently expected to be positively related to numerous undesirable organisational phenomena. For example, low productivity, job dissatisfaction, low workplace-based self-esteem, workplace deviance, disengagement, poor work-life balance, negative diversity attitudes, higher stress levels, absenteeism, strong quit intention and turnover, among others. Conversely, positive perceptions are expected to be negatively related to undesirable organisational phenomena (Botha \& Moalusi 2010; Delobelle et al. 2011; Joubert \& Roodt 2011; Linde et al. 2008; Robbins \& Judge 2013; Searle \& Skinner 2011).

\section{A valid and reliable measure of primary labour relationship quality}

The psychometric properties of the measure of PLQ that were applied in this study were comprehensively described by Ehlers and Jordaan (2016). The measure was reported to be more than adequately valid in light of the fact that all PLQ items were directly derived from a validated typology of desirable social conditions in supervisory relationships, and related labour relations literature. The Chronbach's alpha coefficient of items in the PLQ measure (0.961) far exceeded the minimum acceptable level of 0.7 (Field 2009), which confirmed that the internal reliability and consistency of the instrument is far higher than adequate (Kumar 2011).

\section{Establishing the nature of relationships between variables}

Bartlett's test of sphericity confirmed that variances between PLQ items can be assumed to exist at a confidence level of 0.000. The Kaiser-Meyer-Olkin (KMO) test of sampling adequacy returned a highly desirable value of 0.971 . The aforementioned results confirmed that factor analysis was possible, and a principal component analysis was subsequently conducted (Brown 2009; Field 2009).

Only one underlying component with an Eigenvalue of 11.906 emerged from a principal component analysis. This component accounted for $59.530 \%$ of all variances which far exceeds the $50 \%$ minimum accounting level that was suggested by Hayton, Allen and Scarpello (2004). Furthermore, only two communality values ( 0.328 and 0.431$)$ were lower than the 0.5 level that was recommended (Costello \& Osborne 2005). The other 18 communality values were all higher than 0.5 and fell within a range of 0.517 to 0.726. Communality values, however, do not address the relationship between components and the principal component. Values in the component matrix confirmed that all 20 components were very strongly related to the principal component, with highly desirable factor loadings ranging from 0.573 to 0.852 (Costello \& Osborne 2005). It was therefore concluded that all 20 of the items in the PLQ questionnaire were strongly related to at least one underlying primary 
component, namely 'Primary labour relationship quality (PLQ)' (Costello \& Osborne 2005; Field 2009).

The highly positive factor loading that confirmed strong relationships between the 20 components and PLQ confirmed that additional factor reduction procedures were unnecessary (Brown 2009; Costello \& Osborne 2005; Field 2009). Confirmatory factor analysis falls outside of the scope of the current study and was subsequently not conducted. Appendix 1 contains more specific information on the principal component and factor loadings.

\section{Experimentation and hypothesis testing}

The PLQ measure formed part of a more comprehensive survey questionnaire that also included measures of WSE and quit intention, in addition to a number of biographical questionnaire items. However, PLQ was the main focus of this study and no literature review was subsequently conducted on WSE and quit intention. The availability of the aforementioned additional measurements, however, allowed the researcher to formulate and test five hypotheses on the nature of PLQperceptions, which satisfied the experimentation and hypothesis testing requirement in the theory validation procedure. The five hypotheses and related findings are discussed below:

H1: PLQ perceptions of subordinates are an integrated perception encapsulating interrelated perceptions of the levels of compliance, fairness, good faith and trust in primary labour relationships. This hypothesis was confirmed. A single component (PLQ) with a very high Eigenvalue of 11.906 emerged from the principal component analysis, and factor loadings between PLQ and each of the 20 individual PLQ components were also above the desirable level of 0.5 (0.573 to 0.851 ).

H2: PLQ perceptions of subordinates of different gender, race and age groups are significantly different. This hypothesis was rejected. An independent samples Kruskal-Wallis test confirmed that there are no statistically significant differences in the PLQ perceptions of subordinates from different gender $(p=0.150)$ or race groups $(p=0.078)$. An independent samples Mann-Whitney $\mathrm{U}$ test confirmed that there is no statistically significant difference between the PLQ perceptions of subordinates who are younger than 35 and subordinates who are 35 years or older $(p=0.192)$. The relative significance of these findings, however, suggests that further research should be conducted in this regard.

H3: PLQ levels of subordinates reporting to supervisors from a different gender, race and age group are significantly different. This hypothesis was rejected. An independent samples MannWhitney $\mathrm{U}$ test confirmed that there is no statistically significant difference between the PLQ perceptions of subordinates who report to a supervisor that belongs to a different age group, which were defined as those under 35 and those who are 35 years or older $(p=0.650)$. The same test confirmed that there were no statistically significant differences in the PLQ perceptions of subordinates reporting to a supervisor belonging to a different gender $(p=0.511)$ or different race group $(p=0.461)$.

H4: The WSE levels of subordinates are positively related to their PLQ perceptions. WSE can be defined as a mental state, or personality trait, that an employee develops in accordance with numerous personal experiences within his or her immediate workplace environment over a relatively lengthy time period (David \& Vivek 2012; Heatherton \& Wyland 2003). This hypothesis was confirmed. A Spearman correlation test ( $\mathrm{rs}=$ 0.230) confirmed that there is a highly significant positive correlation between WSE and PLQ perceptions $(p=0.000)$. Positive perceptions of PLQ are therefore strongly related to higher levels of WSE, and vice versa.

H5: PLQ levels of subordinates will be negatively related to their intention to quit. Intention to quit can be defined as an employee or organisational member's intention to leave the organisation in which he or she is currently employed or active (Cho, Johanson \& Guchait 2009). This hypothesis was confirmed. A Spearman correlation test $(\mathrm{rs}=-511)$ confirmed that there is a highly significant negative correlation between quit intention and PLQ perceptions $(p=0.000)$. Negative perceptions of PLQ are therefore strongly related to stronger quit intentions, and vice versa.

\section{Limitations and recommendations}

The PLQ theoretical construct can be regarded as valid for purposes of investigating and analysing labour relations behaviour in supervisory relationships. However, it will not necessarily be valid for analysing the behaviour of groups of employees or managers who are engaged in secondary- and tertiary-level labour relationships. Further related research on the validity of theories on secondary labour relationship exchange quality (SLQ) and tertiary labour relationship quality (TLQ) is subsequently recommended.

This study of PLQ theory was approached from a subordinate's perspective. It should, however, be kept in mind that supervisors also harbour perceptions on PLQ in relationships with their subordinates. The measurement and investigation of supervisor expectations and perceptions on PLQ is therefore recommended.

Even though the factor analysis confirmed that only one underlying factor is present, it is recommended that further statistical analysis of the sub-scale scores on trust, compliance, fairness and good faith be undertaken. This may facilitate further research into the relationships between the aforementioned constructs and other labour relations and organisational variables (Brinkman 2009; Rattray \& Jones 2007).

The relationship between PLQ perceptions of subordinates and two desirable organisational behaviour forms or outcomes were investigated to satisfy the minimum requirements for theoretical construct validation. However, further investigation into relationships between PLQ and other labour relations and organisational behaviour should be undertaken to test the consistency of relationships between positive PLQ perceptions and other desirable organisational variables.

A limited sample was required to achieve the purpose of this study. Caution should thus be displayed when analysing and generalising current research findings for purposes other than theory development and testing (Hair et al. 2006). 


\section{Concluding remarks}

The validity of PLQ as a theoretical construct was investigated in this study. A comprehensive literature review was conducted and a valid and reliable measure was implemented to measure PLQ levels of 454 subordinate employees in the Tshwane region. Literature review and statistical analysis findings were integrated, and the following final conclusions were drawn:

- All subordinate employees, irrespective of age, gender or race, have expectations on formal and psychological contracting outcomes. These expectations inform their perceptions of PLQ. This limited study revealed no statistically significant differences between the PLQ perceptions of respondents with different age, gender or race characteristics.

- Primary labour relationship quality is a theoretical construct that refers to a distinct subjective quality estimate that is assimilated from unique expectations and perceptions of the levels of compliance, fairness, good faith and trust that a supervisor displays in a labour relationship with an immediate subordinate.

- PLQ perceptions of subordinates are significantly related to at least two desirable organisational behaviour forms or outcomes. The study confirmed a statistically significant positive relationship between the PLQ perceptions of subordinates and their WSE, as well as a statistically significant negative relationship between PLQ perceptions of subordinates and their quit intentions.

- It can be confidently assumed that there are significant positive relationships between positive PLQ perceptions and a variety of desirable labour relationship and organisational behaviours and outcomes, and negative relationships between positive PLQ perceptions and undesirable relationship behaviour. Accordingly, it can also be confidently assumed that there are significant positive relationships between negative PLQ perceptions and a variety of undesirable labour relationship and organisational behaviours and outcomes, and a negative relationship between negative PLQ perceptions and desirable relationship behaviour.

The findings from this study can provide a solid foundation for future research into other variables that influence PLQ perceptions, and the relationships between PLQ and other labour relations and organisational behaviour phenomena, such as union affiliation, qualification, position, length of service, deviant organisational behaviour, organisational commitment, organisational culture, organisational values, organisational structure, conflictstyle, motivation, remuneration level, leadership style, POS, leader-member exchange, personality type, personal values, employee engagement, citizenship, job satisfaction, absenteeism, age, race and gender, among others (Chartered Institute of Personnel and Development 2012; De Silva 2014; Ghosh \& Ray 2012; Overell et al. 2010; Robbins \& Judge 2013; Searle \& Skinner 2011).

The PLQ construct also encapsulates a reliable set of behaviour criteria that can be used for objective assessment of PLQ perceptions of subordinates. Such measurements can facilitate effective identification of behaviour development needs of supervisors operating at different levels in organisations. Furthermore, it provides a reliable foundation for developing pro-active labour relations strategies, structures, policies, procedures and behavioural interventions that are needed to effectively prevent and manage labour relations behaviours and outcomes.

The author would like to acknowledge and thank all fieldworkers, colleagues, family and friends that provided support, encouragement, feedback and many other forms of assistance during this project.

\section{Acknowledgements Competing interests}

The author declares that he has no financial or personal relationships that may have inappropriately influenced him in writing this article.

\section{References}

Babbie, E., 2011, Introduction to social research, 5th edn., Cengage Learning Wadsworth, $\mathrm{OH}$.

Bendix, S., 2015, Labour relations: A southern African perspective, 6th edn., Juta Academic, Cape Town.

Bless, C., Higson-Smith, C. \& Sithole, S.L., 2013, Fundamentals of social research methods: An African perspective, Juta, Cape Town.

Botha, L. \& Moalusi, K.P., 2010, 'Values underlying perceptions of breach of the psychological contract', SA Journal of Industrial Psychology 36(1), 1-12.

Brown, J.D., 2009, 'Choosing the right type of rotation in PCA and EFA', Shiken: JALT Testing \& Evaluation SIG Newsletter 13(11), 20-25.

Brinkman, W.P., 2009, Design of a questionnaire instrument: Handbook of mobile technology research methods, Nova Publisher, Delft.

Cho, S., Johanson, M.M. \& Guchait, P., 2009, 'Employees intent to leave: A comparison of determinants of intent to leave versus intent to stay', International Journal of Hospitality Management 28, 374-381. https://doi.org/10.1016/j.ijhm.2008.10.007

Chartered Institute of Personnel and Development (CIPD), 2012, What is employee relations? CIPD, London, viewed 15 February 2016, from http://www.cipd.co.uk/ NR/rdonlyres/B39AFC72-25BD-4C10-B1BA-3564CAC3BBB3/0/whatemprels1105.pdf

Commission for Conciliation, Mediation and Arbitration (CCMA), 2011, CCMA Infosheet: Harassment, CCMA, Johannesburg, viewed 12 February 2011, from http://www.ccma.org.za/UploadedMedia/InfoSheets

Costello, A.B. \& Osborne, J.W., 2005, 'Best practices in exploratory factor analysis: Four recommendations for getting the most from your analysis', Practical Assessment Research \& Evaluation 10(7), 1-9.

Cresswell, J.W., 2014, Research design: Qualitative, quantitative and mixed-methods approaches, 4th edn., Sage, London.

Cropanzano, R., Bowen, D.E. \& Gilliland, S.W., 2007, 'The management of organizational justice', Academy of Management Perspectives 21(4), 34-49. https://doi.org/10.5465/AMP.2007.27895338

Coyle-Shapiro, J.A. \& Shore, L.M., 2008, 'The employee-organization relationship: Where do we go from here?', Human Resource Management 17, 166-179. https://doi.org/10.1016/j.hrmr.2007.03.008

David, E. \& Vivek, P., 2012, 'Exploring the relationship between organization-based self esteem and burnout: A preliminary analysis', Advances in Management 5(3), 54-59.

Delobelle, P., Rawlinson, J.L., Ntuli, S., Malatsi, I., Decock, R. \& Depoorter, A.M., 2011, 'Job satisfaction and turnover intent of primary healthcare nurses in rural South Africa: A questionnaire survey', Journal of Advanced Nursing 67(2), 371-383. https://doi.org/10.1111/j.1365-2648.2010.05496.x

De Silva, S.R., 2014, Elements of a sound industrial relations system, International Labour Organisation, Geneva, viewed 15 November 2014, from http://www.ilo. org/public/english/dialogue/actemp/downloads/publications/srseleme.pdf

Dimatteo, L.A., Bird, R.C. \& Colquitt, J.A., 2011, 'Justice, labour, and the psychological contract', in Selected works, University of Florida, viewed 15 October 2012, from http://works.bepress.com/larry_dimatteo/6

Ehlers, L.I., 2013, 'A typology of desirable employment relationship conditions in supervisory relationships', South African Journal of Labour Relations 37(2), 48-68.

Ehlers, L.I., 2014, 'Social outcomes of labour relationship exchanges in different contracting dimensions', in 8th Annual International Business Conference, Swakopmund, August 19, 2014, pp. 21-32. 
Ehlers, L.I. \& Jordaan, C., 2016, 'A measure of labour relationship quality levels in South African supervisory relationships', Journal of Management and Administration 2016(1), 1-35.

Field, A., 2009, Discovering statistics using SPSS, 3rd edn., Sage, London.

Flanagan, T. \& Runde, C., 2009, 'How teams can capitalize on conflict', Strategy \& Leadership 37(1), 20-22. https://doi.org/10.1108/10878570910926025

Friedman, K., 2003, 'Theory construction in design research criteria: Approaches, and methods', Design Studies 24(6), 507-522. https://doi.org/10.1016/S0142 694X(03)00039-5

Gay, B. \& Weaver, S., 2011, 'Theory building and paradigms: A primer on the nuances of theory construction', American International Journal of Contemporary Research $1(2), 24-32$.

Ghosh, A. \& Ray, P., 2012, 'A contemporary model for industrial relations: Relook from global perspective', Management and Labour Studies 37, 17, viewed 13 February 2014, from http://mls.sagepub.com/content/37/1/17

Grogan, J., 2014, Workplace law, 11th edn., Juta and Company, Cape Town.

Guest, D.E., 2004, 'The psychology of the labour relationship: An analysis based on the psychological contract', Applied Psychology 53(4), 541-555. https://doi.org/10.1111/ j.1464-0597.2004.00187.x

Gerlach, K., Levine, D., Stephan, G. \& Struck, O., 2007, 'Fairness and the labour contract: North American regions versus Germany', Cambridge Journal of Economics 32(3), 421-439. https://doi.org/10.1093/cje/bem040

Hair, J.F., Black, W.C., Babin, B.J., Anderson, R.E. \& Tatham, R.L., 2006, Multivariate data analysis, 6th edn., Pearson Prentice-Hall, Upper Saddle River, NJ.

Hayton, J.C., Allen, D.G. \& Scarpello, V., 2004, 'Factor retention decisions in exploratory factor analysis: A tutorial on parallel analysis', Organizational Research Methods 7(2), 191-205. https://doi.org/10.1177/1094428104263675

Heap, L., 2009, 'Bad faith one day - Good faith the next?', in J. Riley (ed.), The debate Good faith and the labour relationship, pp. 8-9, Australian Institute of Employment Rights, Victoria, Australia.

Heatherton, T.F. \& Wyland, C.L., 2003, Assessing self-esteem. Positive psychological assessment; a handbook of models and measures, APA, Washington, DC.

Holtz, B.C. \& Harold, C.M., 2009, 'Fair today, fair tomorrow? A longitudinal investigation of overall justice perceptions', Journal of Applied Psychology 94(5), 1185-1199. https://doi.org/10.1037/a0015900

Joubert, M. \& Roodt, G., 2011, 'Identifying enabling management practices for employee engagement', Acta Commercii 11(1), 88-110.

Kickul, J., Gundry, L.K. \& Posig, M., 2005, 'Does trust matter? The relationship between equity sensitivity and perceived organizational justice', Journal of Business Ethics 56, 205-218. https://doi.org/10.1007/s10551-004-0992-0

Kumar, R., 2011, Research methodology, 3rd edn., Sage, New Delhi.

Linde, B.B., Schalk, M.J.D. \& Linde, H., 2008, 'Clarity and trust: The experience of workplace regulations by employees', South African Journal of Labour Relations 32(2), 86-103.

Moloto, G.R.B., Brink, L. \& Nel, J.A., 2014, 'An exploration of stereotype perceptions amongst support staff within a South African higher education institution', SA Journal of Human Resource Management 12(1), Art. \#573. https://doi.org/10.4102/ sajhrm.v12i1.573

Navarro, M.D.L.R. \& Cabrera, E.F., 2009, 'A typology of labour relationships', Psychology in Spain 13(1), 72-88.
Nel, P.S., Kirsten, M., Swanepoel, B.J. \& Poissat, P., 2016, South African labour relations, 8th edn., Van Schaik Publishers, Pretoria.

Ntimba, D., 2015, 'Perceived causes of workplace conflict at Zonderwater Management Area', Unpublished MTech dissertation, TUT.

Overell, S., Mills, T., Roberts, S., Lekhi, R. \& Blaug, R., 2010, The employment relationship and the quality of work, Provocation Paper 7, The Good Work Commission, London.

Oxford Press, 2010, Paperback Oxford English dictionary, 10th edn., Oxford University Press, Oxford.

Rattray, J. \& Jones, M.C., 2007, 'Essential elements of questionnaire design and development', Journal of Clinical Nursing 16(2), 234-243. https://doi.org/10.1111/ j.1365-2702.2006.01573.x

Riley, J., 2009, 'Good faith in labour relationships', in The debate: Good faith and the employment relationship, Australian Institute of Employment Rights, Victoria, Australia.

Robbins, S. \& Judge, T., 2013, Organizational behaviour, 14th edn., Pearson, Boston.

Salamon, M., 1987, Industrial relations: Theory and practice, Prentice-Hall, London.

Searle, R.H. \& Skinner, D., 2011, Trust and human resource management, Edward Elgar Publishing Limited, Cheltenham.

Shanock, L.R. \& Eisenberger, R., 2006, 'When supervisors feel supported: Relationships with subordinates, perceived supervisor support, perceived organizational support and performance', Journal of Applied Psychology 91(3), 689-695. https://doi. org/10.1037/0021-9010.91.3.689

Shimanskaya, I., 2010, 'The principle of good faith in European international trade', Unpublished masters dissertation, University of Tampere.

Snow, C.C. \& Thomas, J.B., 1994, 'Field research methods in strategic management: Contributions to theory building and testing', Journal of Management Studies 31(4), 457-480. https://doi.org/10.1111/j.1467-6486.1994.tb00626.x

Soko, M. \& Balchin, N., 2014, Breaking the deadlock: Tackling the South African labour market crisis, UCT GSB Business Review 2014(2), viewed 20 February 2016, from http://www.gsbbusinessreview.gsb.uct.ac.za/breaking-the-deadlock-tacklingthe-south-african-labour-market-crisis

Southey, K., 2010, 'A typology of employee explanations of misbehaviour: An analysis of unfair dismissal cases', Journal of Industrial Relations 52(1), 81-102. https:// doi.org/10.1177/0022185609353991

Sparrow, P.R. \& Cooper, C.L., 2003, The labour relationship. Key challenges for $H R$ Butterworth-Heinemann, London.

Tekleab, A.G. \& Taylor, M.S., 2003, 'Aren't there two parties in an labour relationship? Antecedents and consequences of organization-employee agreement on contract obligations and violations', Journal of Organizational Behavior 24(5), 585-608. https://doi.org/10.1002/job.204

Tepper, B.J., 2007, 'Abusive supervision in work organizations: Review, synthesis, and directions for future research', Journal of Management 33, 261-289. https://doi. org/10.1177/0149206307300812

Theledi, N.L., 2015, 'Employment relationship satisfaction of constables in the South African Police Service in the Tshwane region', Unpublished masters dissertation, Tshwane University of Technology, Pretoria.

Venter, R. \& Levy, A. (eds.), 2014, Labour relations in South Africa, 5th edn., Oxford University Press, Cape Town.

Williams, M., 2007, 'Building genuine trust through interpersonal emotion management: A threat regulation model of trust and collaboration across boundaries',
The Academy of Management Review 32, 595-621. https://doi.org/10.5465/ AMR.2007.24351867 


\section{Appendix 1:}

\section{Factor analysis results}

TABLE 1-A1: Kaiser-Meyer-Olkin and Bartlett's test.

\begin{tabular}{lcc}
\hline Test & Variable & Value \\
\hline Kaiser-Meyer-Olkin Measure of Sampling & - & 0.971 \\
Adequacy. & & \\
Bartlett's test of sphericity & Approx. chi-square & 7022.765 \\
& $d f$ & 190 \\
& Sig. & 0.000 \\
\hline
\end{tabular}

$d f$, degrees of freedom; Sig., significance.

TABLE 2-A1: Total variance explained.

\begin{tabular}{|c|c|c|c|c|c|c|}
\hline \multirow{2}{*}{ Component } & \multicolumn{3}{|c|}{ Initial eigenvalues } & \multicolumn{3}{|c|}{ Extraction sums of squared loadings } \\
\hline & Total & $\%$ of variance & Cumulative $\%$ & Total & $\%$ of variance & Cumulative $\%$ \\
\hline 1 & 11.906 & 59.530 & 59.530 & 11.906 & 59.530 & 59.530 \\
\hline 2 & 0.932 & 4.659 & 64.188 & - & - & - \\
\hline
\end{tabular}

Note: Extraction method: principal component analysis.

TABLE 3-A1: Principal components analysis communalities and component matrix.

\begin{tabular}{|c|c|c|}
\hline Items & $\begin{array}{l}\text { Communalities between } \\
\text { item and other items }\end{array}$ & $\begin{array}{l}\text { Relationship between } \\
\text { items and one extracted } \\
\text { component }\end{array}$ \\
\hline 1. Compliance & 0.544 & 0.738 \\
\hline 2. Fairness & 0.547 & 0.740 \\
\hline 3. Good faith & 0.618 & 0.786 \\
\hline 4. Trust & 0.607 & 0.779 \\
\hline 5. Compliance & 0.517 & 0.719 \\
\hline 6. Fairness & 0.328 & 0.573 \\
\hline 7. Good faith & 0.724 & 0.851 \\
\hline 8. Trust & 0.726 & 0.852 \\
\hline 9. Compliance & 0.613 & 0.783 \\
\hline 10. Fairness & 0.679 & 0.824 \\
\hline 11. Good faith & 0.675 & 0.822 \\
\hline 12. Trust & 0.556 & 0.746 \\
\hline 13. Compliance & 0.431 & 0.657 \\
\hline 14. Fairness & 0.525 & 0.725 \\
\hline 15. Good faith & 0.713 & 0.845 \\
\hline 16. Trust & 0.537 & 0.733 \\
\hline 17. Compliance & 0.608 & 0.780 \\
\hline 18. Fairness & 0.615 & 0.784 \\
\hline 19. Good faith & 0.636 & 0.797 \\
\hline 20. Trust & 0.706 & 0.840 \\
\hline
\end{tabular}

